\title{
"Which door should I go through?": (In)visible intersections of race and disability in the academy
}

\section{Area (SJR 0.99)}

\section{Amita Bhakta}

School of Architecture, Building and Civil Engineering, Loughborough University, Loughborough, Leicestershire, LE11 3TU

\section{A.N.Bhakta@Iboro.ac.uk}

\section{ABSTRACT}

Institutional inclusivity and diversity have been an increasing focus of debate within the academy. For the discipline of geography and universities more broadly to become fully inclusive, greater attention is warranted within these debates upon the intersection of race and disability. Lack of debate on race-disability issues in the academy draws attention to the invisibility of disabled academics of BME backgrounds. Drawing upon examples of spaces of (mis)recognition and of indifference inside and outside the space of the British academy, this paper calls for greater attentiveness in geography and beyond to socio-cultural and spatial issues faced by ethnic minority disabled members of the university community which are otherwise hidden. A focus upon these hidden issues in research agendas, institutional practices and the academy more broadly is warranted to enable the university to strive towards greater inclusivity.

\section{ACKNOWLEDGEMENTS}

The author would like to thank Dr James Esson for his constructive guidance on earlier versions of this paper, the reviewers for their useful feedback on the initial submission, and Dr Angela Last for useful comments on the final draft. 


\section{KEY WORDS}

Race, disability, inclusivity, mis/recognition, academy, institutional

\section{"Which door should I go through?": (In)visible intersections of race and disability in the academy}

\section{ABSTRACT}

Institutional inclusivity and diversity have been an increasing focus of debate within the academy. For the discipline of geography and universities more broadly to become fully inclusive, greater attention is warranted within these debates upon the intersection of race and disability. Lack of debate on race-disability issues in the academy draws attention to the invisibility of disabled academics of BME backgrounds. Drawing upon examples of spaces of (mis)recognition and of indifference inside and outside the space of the British academy, this paper calls for greater attentiveness in geography and beyond to socio-cultural and spatial issues faced by ethnic minority disabled members of the university community which are otherwise hidden. A focus upon these hidden issues in research agendas, institutional practices and the academy more broadly is warranted to enable the university to strive towards greater inclusivity.

\section{ACKNOWLEDGEMENTS}

The author would like to thank Dr James Esson for his constructive guidance on earlier versions of this paper, the reviewers for their useful feedback on the initial submission, and Dr Angela Last for useful comments on the final draft. 


\section{KEY WORDS}

Race, disability, inclusivity, mis/recognition, academy, indifference,

\section{INTRODUCTION}

Inclusivity and diversity debates within the academy have gained momentum in recent years. The Race Relations (Amendment) Act 2000 provoked a flurry of policy and complex strategic action plans in higher education (Mirza, 2006), founded in the principles of 'respecting diversity in order to achieve equality' (Bhavnani et al, 2005: 87). The Athena SWAN Charter, founded in 2005, shifted the focus of discussion around inclusion towards eliminating discriminatory practices and encouraging family friendly practices to enable equal opportunities for women. Athena SWAN illustrates how universities are striving for inclusivity through the employment of women in STEM in higher education, to reflect gender equality (Barrett, 2017). At times however, concerns of inclusivity do not focus upon unitary aspects of identity alone. Structural intersectionality (Crenshaw, 1997), enables an exploration of hidden issues faced by individuals as a result of multiple levels of exclusion, such as race and gender. Exclusion of racialised women in the British political workplace has been explored by Puwar (2004:141) who asks, 'what happens when those embodied differently come to occupy spaces rarely occupied by them?', thereby marking racialised bodies, and racialised women in particular as 'space invaders' (Puwar, 2004).

Debates around diversity in the academy have been critiqued. Universities have been scrutinised for claiming 'diversity' when in fact it is non-performative, with little evidence of action on the matter (Ahmed, 2006; 2007). This is because institutional arrangements both sanction and normalise 'microaggressions' experienced by academics and by individuals in 
everyday life generally (Esson et al, 2017; Tate, 2014; Mbembe, 2016). As Mahtani (2014) states, Indigenous and non-white geographers are made invisible through 'emotionally toxic material spaces' and liberal discourses within them. Tolia-Kelly (2010) argues that the interface between the academy and the other (i.e. people of race) needs to shift to more of an international outlook in its' praxis. Activism in the academy is needed to challenge the imperialist-white, supremacist-capitalist patriarchy globally, by being more inclusive of race (hooks, 2004). This paper extends these debates to look at improving and integrating inclusivity practices in the university to reach out to disabled academics of race, who are hidden within the academy (Miles et al, 2017) and beyond despite their visible markers of identity through the colour of their skin and (if physical) disability. Improving academic praxis regarding race theory, across disciplines including geography, is needed not only to raise the profile of disabled academics of race within the space of the university, but also to recognise more explicitly the presence of disabled people of colour within society. As this paper discusses, issues of intersectionality when it comes to race and disability manifest within the space of the university classroom, and in diverse parts of the city.

Individuals with multiple identities and therefore multiple levels of exclusion face dilemmas at a personal level in a higher education context, raising questions for the institutional practices of the academy. Which door should the disabled, ethnic minority female student or academic go through for support? How can they be sure who can best address individual issues faced as a consequence of the intersections of their identity? The equalities and race officer may not be fully aware of the complex issues of disability. It cannot be assumed that the disability officer understands how exclusion manifests through race. Drawing upon personal examples as a British Indian researcher with Cerebral Palsy, I argue that debates around academic practice need to interrogate and understand further the deployment of 
intersectionality in the academy and its' effects. I call for longer term inclusive practices to enable the university to be more reflective of modern society, by paying greater attention to the intersection of race and disability.

\section{RACE AND DISABILITY: (IN)VISIBLE INTERSECTIONALITY IN THE ACADEMY}

Some forms of intersectionality have received more coverage than others. Attention upon racial conflict in the university (Harper and Hurtado, 2007) has broadened to include debates about religion, sexual orientation and gender as other layers of identity (Elliot II et al, 2013). Intersectionality as previously adopted by geographers has been problematic. Harvey's (1993) claim that 'progressive' class-based politics were being fragmented through a focus upon the specificities of sexual and racial oppression, were critiqued by authors such as Young (1998), who argued that social movements on class failed to be inclusive of all and led to movements on gender and race. Crenshaw (1991) summarised that under this view of intersectionality, one category of identity is viewed as dominant over others. Therefore, individuals with two or more identity categories are ignored in debates. Discussions on intersectionality have been critiqued by Crenshaw (1991) who argued that there has previously been insufficient care taken in exploring relations between race and gender from a civil society, political and academic perspective. In particular, Crenshaw (1991) argues that black or ethnic minority women are marginalised and political attention does not engage with the particular difficulties which they face as a direct result of the intersection of their identities. As Crenshaw (1991: 1253) summarises, 'Women of colour can be erased by the strategic silences of antiracism and feminism'. Instead Crenshaw (1991) argues for a structural intersectionality, which examines the intersection of unequal social groups; structures can make certain groups 
become and enact vulnerability. Disabled women of colour are excluded from disability studies which inform academic institutional change (Miles et al, 2017) as a result of the convergence of race, disability and gender.

Issues around inclusivity in the university have become increasingly fluid and complex (Obear, 2012). Whilst these debates have gained momentum, little discussion has focussed upon the intersection of race and disability, which is conspicuous by the absence and invisibility of disabled academics of black and minority ethnic (BME) backgrounds participating in academic debates and physically within university campuses. Disabled, BME students and staff are sparsely visible in the university campuses of the global North (Knight and Oesterreich, 2002; Reid and Knight, 2006; Miles et al, 2017) as well as the global South. In an open letter, Miles et al (2017) (as disabled women of colour), called for disability studies to acknowledge issues of race faced by disabled people, alongside those of gender, class and other forms of exclusion. This acknowledgement need not be restricted to academic study in disability studies or geography or related fields, but to wider practices in the neo-liberal university. The university does not act as a space for the informal discussion of race-disability issues, between students peer-to-peer, nor between students and academics. Student services are tailored to a 'norm' of being, white, able-bodied and privileged, blind to the ethnic minority disabled student. Turn the pages of a university prospectus, and seldom will there be an image of a student of colour with an evident disability. Evidence of an ignorance of these issues is apparent in practices inside the university and in the ways in which the university engages with wider society through outreach and recruitment. When visiting an university open day, the sparse images of the ethnic minority disabled student in prospectuses is reflected in reality with their infrequent involvement in helping at open days, confined to the department or to managing the main desk, unable to take visitors on campus tours. Never are we present 
at outreach activities in secondary schools; able-bodied, white students are given priority over us when selecting representatives.

Lack of debate around race-disability as co-constituting identities in the academy and beyond in the global North, comes into sharper focus when the hiddenness of minority disabled academics in the global South on the rare occasion falls under the lens of the media. In 2015, the $\mathrm{BBC}$ reported upon Dr Akshansh Gupta, an Indian man with Cerebral Palsy who attained his PhD at Jawaharlal Nehru University (BBC, 2015). Dubbed the 'Stephen Hawking of India', Dr Gupta has actively sought to challenge inherent exclusion of people with disabilities which manifest through anti-disability legislation (India Today, 2015). Yet, when the media highlights race-disability issues in the academy (in the global South in particular), it consigns them to be a fetish. Presentation of racialised disabled bodies through the media risks an inadvertent segregation through labelling individuals as 'inspirational' for 'overcoming' personal challenges which separate us from others, instead of trying to normalise our identity as part of society, in the academy as professional experts, and beyond. Society, through the media, needs to heed caution; should they ask BME disabled academics to participate in news bulletins or documentaries because our race and disability collectively sets us apart as individuals 'unique' to and socially invisible through the academy? Doing so may distract from our identity as academics with expertise in a particular field, something which is part of a way of 'normalising' our lives without letting disability and race overshadow them. 


\section{GEOGRAPHY MATTERS: SPACES OF MIS/RECOGNITION AND SPACES}

\section{OF INDIFFERENCE}

Intersectionality of race and disability and the attendant issues arising from it are inherently spatial, within different spaces which interrelate, and thus should be a concern for geographers. For Massey (2005:10), 'space does not exist prior to identities and entities and their relations [...] the relations 'between' them and the spatiality which is part of them, are all co-constitutive'. Space is not holistic and does not act as a container for always/already constituted identities, as there are missing links and loose ends, therefore space needs to remain open (Massey, 2005). This paper explores the intersection of race and disability in spaces of (mis)recognition (Massey, 2005), whilst also recognising the need to allow disabled people of race to occupy spaces of indifference (Tonkiss, 2003). For Berlant (2011: 122), to misrecognise is to 'project qualities onto something'. Through misrecognition, a person is 'denied the status of a full partner in social interactions, as a consequence of institutionalised patterns of cultural value that constitute one as comparatively unworthy of respect or esteem' (Fraser, 2000:113-4). Spaces of misrecognition can mean that marginalised groups suffer because spaces can mark them out, make them feel noticed or on the other hand invisible, not taken seriously or even demeaned (Young, 1990). Misrecognition and recognition are situational, co-constituted, relational and imbued with power, dependent upon space and time (Hopkins et al, 2017). Conversely, spaces of indifference consider the politics and ethical relations of enabling city residents to live 'side-by-side', and where differences are lived in everyday social spaces. Spaces and ethics of indifference facilitate a sense of freedom within the space of the city, with the (at times lonely) liberty that no-one is looking or listening (Tonkiss, 2003). Yet, it is plausible that spaces of indifference invoke the 
right to be lonely (Riley, 2002), to have a sense of anonymity, and to have a lack of concern for others, even if this is only temporary (Tonkiss, 2003).

From my experiences, spaces of mis/recognition and of indifference shape how I experience the three strands of my identity (academic, BME, disabled) : individually as a researcher, institutionally within the university, and in wider society. This section interrogates experiences in which intersections of race and disability conflict in some spaces, but co-exist in others, using personal examples from inside and outside of the academy.

\subsection{Mis/recognition and indifference as a researcher}

The relevance of race-disability intersections to geography come into focus in the field, through interaction with others through fieldwork in the global South. As a discipline, geography has helped to legitimise whiteness through practices such as fieldwork (Abbott, 2006). Fieldwork is based upon notions of imperialist explorations to feed contemporary ideas of 'the west and the rest' (Abbott, 2006:333), thereby making whiteness invisible because whiteness is seen as 'the natural order of things' (Bonnett, 1997: 198). Disabled ethnic minority researchers are also erased from the landscape of the field, with the traditional constructs of field researchers in geography as able-bodied, white, masculine, youthful and able to manage difficult terrain (Hall et al, 2002).

A female, disabled, Asian researcher working on water and sanitation in urban Ghana, faces different levels of recognition and misrecognition, difference and indifference, according to the capacity in which she is working. In the urban Ghanaian low-income community, the researcher is recognised as a professional exploring issues relevant to the local community. Whilst being a researcher of colour with ethnic origins in the global South, with brown skin colour as a marker of indifference, local taboos around disability are less applicable as an 
external stakeholder from the global North. It begs the question, are non-white researchers seen to better understand issues of the global South than their traditionally white, (often male) counterparts, in sharp contrast to conventional understandings of development fieldwork? The role of being an academic comes to the fore as positive regardless of (dis)ability in the community context, if geography acknowledges the intersections of identities of gender, race and (dis)ability. Working in the field of the global South provides scope for indifference to become more prominent. As the Asian, brown-skinned researcher wanders the streets of low-income urban communities in Accra and Kumasi, over time, she gradually blends in as she meets local people on an almost daily basis, dressed in local traditional clothing, residents enthused by exchanges held in Ga and Twi, accompanied by smiles. These experiences are far-removed from hostilities between the migrant South Asian communities in Dar-es-Salaam and the local Tanzanian population, where landmarks such as Hindu temples became sites of gendered resistance against an emerging power struggle between Tanzanians and Asians (Nagar, 2000).

In contrast, enablement in the field is contested when some intersectionalities take precedence over others. Working in a research team with an older, male Ghanaian assistant as a young female Asian raises issues of misrecognition and (un)acceptance as a colleague in a patriarchal society. As humanitarian workers in the global South, researchers are expected to be competent and to provide relief beyond normal professional codes of conduct (Reed and Fereday, 2016). Disability limits the competency of the researcher to meet the economic demands of the team, through limited working hours in the field and unexpected changes to the research schedule due to lack of physical wellbeing. Interruptions to planned fieldwork could almost be seen as inevitable where an unpredictable body with Cerebral Palsy is concerned, but this does not lessen the anxiety of ensuring that the researcher is seen as 
responsible towards local people, as culturally aware, and as a 'good' academic ever present in the field. Debates on conducting research in the global South have considered the ways in which we as academics can be responsible to the people we are working with (Cameron and Gibson, 2005; Moseley, 2007; Bhakta et al, 2015). This responsibility can, however, be balanced and situations where responsibility can be at risk, can be abated through connection to community. A leave of absence of the researcher over a period of a few days due to illness is counteracted by a sense of concern from communities in Accra and Kumasi as to the researcher's wellbeing, provoking feelings of belonging, care, compassion and acceptance, as residents cheer with excitement on her return as fieldwork recommences. Playing with the children in the streets of the community in brief moments, away from fieldnotes, interviews, and focus groups, adds further to a sense of happiness, of normality, of simply being indifferent, without the cloak of disability to overshadow it, reigniting memories of similar, first experiences of fieldwork in the global South with slum children in Kenya (Bhakta et al, 2015). Reconnecting to people and place after even the shortest of absences is critical to the effective ethical and practical conduct of fieldwork, particularly where disabled researchers, and moreover disabled researchers of colour are concerned, in order to facilitate good academic praxis in the global South which cares for research participants, community, researchers, and good research itself. Accountability towards the local research team, whilst contested through disability, within frameworks of cultural and academic responsibilities of a researcher in the field of the global South, can be addressed and a sense of indifference can be created through collective care for participants, locals, and researcher. 


\subsection{Mis/recognition and indifference as a scholar}

Institutionally based academic activities highlight the relative hiddenness of BME academics and students with disabilities in the academic community. BME students are a minority in undergraduate geography degrees. Geographers of race experience racial microaggressions in their departments, with longer term impacts upon their wellbeing. Invisible racist remarks and practices claimed by BME geographers are produced but ignored, at the scales of individual bodies, classrooms and departments, creating visceral experiences of discomfort in the discipline of geography (Joshi et al, 2015). It is of note therefore, that only one student of Asian ethnicity with a visible disability sits in a lecture theatre in a large geography class, isolated and alone on the end of the benches, with notetaker in tow sitting by her for support, which sets her apart but at the same time is invisible to the rest of the class. The enthusiasm of the undergraduate student to openly both pose questions to and answer questions from lecturers could at times be subdued by isolation and uncertainty about which 'group' to join when groupwork was assigned, and where she would be accepted. In the corridors outside, the Asian disabled student silently and invisibly passes through the sea of white, able-bodied students, searching for the friendliest-looking faces, finding a handful of select people to mingle with.

Academic international conferences and workshops are spaces of hypervisibility. BME academics with disabilities are seldom seen and heard in a professional capacity. Whether at the Annual RGS-IBG Conference in London, or the Water, Engineering and Development Centre (WEDC) Conferences held from Hanoi to Nakuru to Kumasi, the presence of the singular, disabled, BME researcher with a speech and physical impairment delivering a paper to a full-to-capacity audience is vivid, creating spaces of recognition for an individual who is 
relatively hidden from view in wider society. Yet conversely, these spaces do not acknowledge disabled conference attendees. RGS-IBG conferences present a tiring, long-distance gauntlet for the physically wobbly geographer with Cerebral Palsy to negotiate, with sessions spaced widely apart between the RGS-IBG and Imperial College, and the many bodies with conference badges running along Exhibition Road to attend sessions to avoid bumping into as a result of an unsteady gait. In Hanoi, Nakuru and Kumasi, the WEDC conferences hosted at local universities reflect the relative hiddenness of disabled academics of race globally, and particularly in the Global South. An absence of lifts and many flights of stairs to access the conference rooms in Vietnamese, Kenyan and Ghanaian universities are markers of exclusion for disabled people of race in higher education. Thus, whilst the activity of presenting papers at conferences leads to hypervisibility, disabled academics of race are erased from the landscapes and spaces in which conferences occur.

Publications and research by academics from different disciplines may provide indications of their race, but not of their disability. Geography and other disciplines have subsequently neglected the issues surrounding the inclusion of BME academics with disabilities in their research practices. This absence of research combined with sparse hypervisibility highlights needs for greater institutional debate and reform for better inclusivity.

\subsection{Mis/recognition and indifference in my city}

The racialized disabled body is not just hidden from the academy, but from society too. For Amin (2002:967), 'diversity is thought to be negotiated in the city's public spaces'. Amin (2002) refers to Leicester, which uses public space to celebrate diversity through events such as Diwali and a Caribbean carnival. Yet, wander the streets of the diverse area of Belgrave in 
inner city Leicester, and the significant population of disabled, South Asian residents are seldom seen. Our presence is marked only through the many disabled parking spaces outside the rows of terraced houses, which are retrofitted with handrails. Intra-racial attitudes and cultural stigmas leave South Asian people with disabilities side-lined, compounded by community-based cultures of dependency which limit their movement through spaces and society. Disabled residents in culturally diverse parts of the city are disengaged from educational opportunities due to engrained community-based cultural perceptions that they lack intelligence, and in turn excluded from the community due to abjection, seldom touched through handshakes or hugs. Touch loses its' sense of affect and relational characteristics for people when the abjection of racial others (Gilroy, 2004) and the coloniality of power (Gutiérrez Rodríguez, 2010) are concerned. Dirty effects of disgust and contempt are ever present (Warmington, 2014; Pilkington, 2011; Hylton, 2008; Meer, 2010) for bodies of race. For disabled bodies of colour, there are double layers of contempt and disgust; contempt for our dark skin is hand in hand with contempt for our uncontrollable drooling as a marker of dirt. In society, the intersectionality of race and disability therefore leads to a certain negative nature of affect, leading to the hiddenness of disabled people of race.

\section{MOVING FORWARD: RESHAPING THE ACADEMY, RESEARCH AGENDAS, AND INSTITUTIONAL PRACTICES}

Inclusivity in the university requires evaluation and adaptation to recognise how members of its' community are excluded through intersecting identities and through spaces of misrecognition. Exclusion through race and disability warrants attention, if the BME student or staff member with a disability is to be fully included and the university is to become a space of indifference, rather than of misrecognition. As academics, should we begin the process of 
including BME academics with disabilities through our research agendas? Exploring the cultural discourses which facilitate exclusion of BME students with disabilities from education widens the discussion surrounding barriers of entry to $\mathrm{HE}$, to explore race and disability as coconstituent identities. The presence of the few BME, disabled academics and students in the academy is noteworthy; unless they are able to break through the barriers of cultural stigmas in society, they cannot access spaces of enablement through the academy in a professional capacity. Revealing the experiences of the few BME academics with disabilities would illustrate their ill-discussed exclusion generally. Greater awareness of cultural experiences outside the academy could inform inclusivity inside the academy. As these issues are interrogated, there is scope for research teams to reflect what they seek to achieve in their practices, by including $\mathrm{BME}$, white, disabled and able-bodied researchers. A participatory agenda would ensure the active involvement of BME researchers with disabilities, rather than to view them as beneficiaries of any outcomes of the study alone.

Analysing issues of race and disability through spaces of (mis)recognition and indifference can help to shape institutional practices. These spaces can help to shift and to challenge the 'norms' of whiteness and ableism in both geographical and institutional praxis. Looking at race-disability tensions through space provides scope to move beyond these entrenched discourses to create greater visibility for disabled people of colour in the academy, which is sensitive to culture and physical ability in the classroom, department, conferences, the field and more. Diversity practices could be improved by highlighting the hiddenness of BME academics with disabilities, with the aim of becoming more reflective of modern society and the diversity within it. However, this would need to be done with great care, after highlighting and seeking to address the hiddenness of disabled BME academics, to then normalise inclusive practices, such as through promoting their participation on departmental 
committees for inclusion, but also facilitating normal practices such as teaching classes which are about their research, which may be about topics other than race and disability. This in turn creates a regular academic practice where recognising and engaging with race-disability issues become the norm. Gazing upon race-disability issues in space draws attention to the lack of understanding of what intersectionality truly means to geography in practice, and where the gaps still remain. Spatialising these issues in turn provides scope for geographers to shift their research agenda to explore race-disability (and other layers of identity) collectively, rather than to employ a unitary approach to geographies of difference and identity.

Institutionally, the door for the BME disabled student or staff member to enter for support requires clearer signposting. Behind it, should sit a qualified person who is able to provide collective pastoral support which deals with multiple levels of exclusion simultaneously, to address issues of race, of disability and the repercussions of the ways in which they are intertwined. Diversity in front of the door requires diversity behind it.

Universities have scope for engagement with communities which create spaces of microaggressions for BME individuals with disabilities. Outreach work with these communities can showcase the potential of greater inclusion of disabled people of race in society generally, using the example of the institution. A unified approach to inclusivity by academics of race, white academics, those disabled and able-bodied, and across gender and class, paves the way forward to connect academic work to society. Only then can the racialized disabled body become visible and recognised as an active participant of society, in the academy and beyond. 


\section{REFERENCES}

\section{ADD MISSING REFS FROM PROOFS}

Abbott D 2006 Disrupting the whiteness of fieldwork in geography Singapore Journal of Tropical Geography 27 326-341

Ahmed S 2007 'You end up doing the document rather than doing the doing': Diversity, race equality and the politics of documentation Ethnic and Racial Studies 30 590-609

Ahmed, S 2006 Doing Diversity Work in Higher Education in Australia Educational Philosophy and Theory 38 745-768

Amin, A 2002 Ethnicity and the multicultural city: living with diversity Environment and Planning A 34 959-980

Barrett, A 2017 Women at Imperial College, Past, Present and Future World Scientific, New Jersey

BBC 2015 Akshansh's PhD: India man who didn't let cerebral palsy win (http://www.bbc.co.uk/news/av/world-asia-india-34981330/akshansh-s-phd-india-manwho-didn-t-let-cerebral-palsy-win ) Accessed 4 November 2017

Berlant L 2011 Cruel Optimism Duke University Press, Durham

Bhakta, A., Dickinson, J., Moore, K., Mutinda, D., Mylam, A., and Upton C 2015 Negotiating the responsibilities of collaborative undergraduate fieldcourses Area 47 282-288

Bhavnani, R, Mirza, H.S. and Meetoo, V 2005 Tackling the Roots of Racism: lessons for success Policy Press, Bristol 
Bonnett A 1997 Geography, 'race' and whiteness: invisible traditions and current challenges Area 29 193-9.

Cameron J and Gibson K 2005 Participatory action research in a poststructuralist vein. Geoforum 36 315-31

Crenshaw, K. 1991. Mapping the margins: Intersectionality, identity politics and violence against women of colour. Stanford Law Review, 43, 1241-1299. https://doi.org/10.2307/1229039

Crenshaw, K 1997. Beyond racism and misogyny: black feminism and 2 live crew in Cohen C, Jones K and Tronto J eds Women Transforming Politics: An Alternative Reader New York University Press, New York, 549-568

Elliot II, C.M., Stransku, O., Negron, R., Bowlby, M., Lickiss, J., Dutt, D., Dasgupta, N., and Barbosa, P. 2013. Institutional barriers to diversity change: work in higher education SAGE Open 3 (online only)

Esson, J., Noxolo, P., Baxter, R., Daley, P., and Byron, M. 2017. The 2017 RGS-IBG chair's theme: decolonising geographical knowledges, or reproducing coloniality Area 49 384-388

Fraser N 2000 Rethinking recognition New Left Review 3 107-20

Gilroy P 2004 After Empire-Melancholia or Convivial Culture? London, Routledge Gutiérrez Rodríguez, E 2010 Migration, Domestic Work and Affect: A Decolonial Approach on Value and the Feminization of Labor. Abingdon, Routledge Hall T, Healey M and Harrison M 2002 Fieldwork and disabled students: discourses of inclusion and exclusion Transactions of the Institute of British Geographers 27 312-231 
Harper, S R and Hurtado, S 2007 Nine themes in campus racial climates and implications for institutional transformation New Directions for Student Services 120 7-24

Harvey D 1993 Class relations, social justice and the politics of difference. In S Pile and M Keith eds Place and the politics of identity Routledge, London 41-66.

hooks b 2004 We real cool: Black men and masculinity Routledge, New York

Hopkins P, Botterill K, Sanghera G and Arshad R 2017 Encountering Misrecognition: Being Mistaken for Being Muslim Annals of the Association of American Geographers 107 934-948

Hylton K 2008 Race and Sport: Critical Race Theory Routledge, London

India Today (2015, December 3) World Disability Day: A salute to the scholar who fought cerebral palsy to complete his PhD. Retrieved from http://indiatoday.intoday.in/story/world-disability-day-a-salute-to-the-scholar-who-foughtcerebral-palsy-and-completed-phd-from-jnu/1/537491.html

Joshi S, McCutcheon P and Sweet EL 2015 Visceral Geographies of Whiteness and Invisible Microaggressions ACME: An International E-Journal for Critical Geographies 14 298-323

Knight M and Oesterreich H 2002 (In)(di)visible youth identities: Insight from a feminist framework. In W. G. Tierney \& L. Hagedorn eds Increasing access to college State University of New York Press, New York 123-144.

Mahtani M 2014 Toxic geographies: absences in critical race thought and practice in social and cultural geography Social and Cultural Geography 15 359-67

Massey D 2005 For Space Sage, London 
Mbembe A J 2016 Decolonizing the university: new directions Arts and Humanities in Higher Education 15 29-45

Meer N 2010 Citizenship, Identity and the Politics of Multiculturalism Palgrave Macmillan, Basingstoke

Miles, A.L., Nishida, A. and Forber-Pratt, A.J. 2017 An open letter to White disability studies and ableist institutions of higher education. Disability Studies Quarterly 37 (online only)

Mirza, H.S 2006 Transcendence over Diversity: black women in the academy Policy Futures in Education 4 101-113

Moseley W 2007 Collaborating in the field, working for change: reflecting on partnerships between academics, development organizations and rural communities in Africa Singapore Journal of Tropical Geography 28 334-47

Nagar, R. 2000 I'd rather be rude than ruled: Gender, place and communal politics among South Asian communities in Dar es Salaam Women's Studies International Forum 23, 571-585

Obear, K. 2012 Reflections on our practice as social justice educators: How far we have come, how far we need to go. Journal of Critical Thought \& Praxis $131-52$

Pilkington A 2011 Institutional Racism in the Academy Routledge, Abingdon

Puwar, N. 2004 Space Invaders: Race, Gender and Bodies out of place Berg, London

Reed B.J and Fereday E 2016 Developing professional competencies for humanitarian engineers Proceedings of the Institution of Civil Engineers - Civil Engineering 169 49-56

Reid, K and Knight M 2006 Disability justifies exclusion of minority students: a critical history grounded in Disability Studies Educational Researcher 35 18-23 
Tate, S. A. 2014 Racial affective economies, disalienation and 'race made ordinary' Ethnic and Racial Studies 37 2475-90

Tolia-Kelly, D. 2010 The geographies of cultural geography I: identities, bodies and race Progress in Human Geography 34 358-367

Tonkiss, F. 2003 The ethics of indifference: Community and solitude in the city. International Journal of Cultural Studies, 6, 297-311. https://doi.org/10.117/13678779030063004

Warmington P 2014 Black British Intellectuals and Education: Multiculturalism's Hidden History Routledge, Abingdon

Young I.M 1998 Harvey's complaint with race and gender struggles: A critical response. Antipode 30 36-42.

Young I M 1990 Justice and the politics of difference Princeton University Press, Princeton 